\title{
Age-related Effects of Norepinephrine on Rat Ventricular Hypertrophy
}

\author{
Hiroaki Hamada, MD, Naohiro Hakamata, MD, \\ Fumitaka OHsuzU, MD, \\ and Haruo NAKAMURA, MD
}

\section{SUMMARY}

Norepinephrine (NE) $(2.5 \mu \mathrm{g} / \mathrm{kg} / \mathrm{min})$ was administered to 5-week-old male Sprague Dawley rats by subcutancous osmotic mini pumps for 14 days to generate an in vivo cardiac hypertrophy model and the responses with respect to aging examined. In the model, ventricles were significantly hypertrophied without myocardial necrosis and without significant increases in heart rate or blood pressure; the beta adrenergic system was down-regulated. In 37-week-old rats receiving $1.0 \mu \mathrm{g} / \mathrm{kg} / \mathrm{min} \mathrm{NE}$, there was a tendency towards heart failure, and myocardial necrosis and interstitial fibrosis were revealed by histological examinations. The density of beta adrenergic receptors and adenylyl cyclase activity was lower in the older rats. The excess stimulation of adrenergic receptors caused severe cardiac injury in old rats regardless of down regulation of beta adrenergic receptors. (Jpn Heart J 1997; 38: 433-443)

Key words: Sympathetic nervous system, Norepinephrine, Ventricular hypertrophy, Osmotic mini pump, Aging

Or

ULTURED neonatal cardiomyocytes have been used to determine the role of $\alpha$ adrenergic stimulation in cardiac hypertrophy. ${ }^{1,2)}$ Because many factors interact in in vivo experimental systems, it is often difficult to decide which factor(s) most profoundly affect the results. There are limitations in cultured cardiomyocyte systems, so both in vivo and in vitro experimental systems are needed to uncover the relevant factors. Among in vivo experimental systems, reports differ with respect to the changes of catecholamine concentrations of myocardium $^{3,4)}$ and the response of myocardium to $\alpha$ and $\beta$ adrenergic blockers. ${ }^{5,6)}$ The tonus of sympathetic nervous systems is believed to be different in the different models. Cooper et al. ${ }^{7)}$ suggested that mechanical stimulation may be the most important factor for cardiac hypertrophy in adults. It is reasonable to assume that animal species and ages may also be affecting factors. In the present

From the Department of Medicine I, National Defense Medical College, Saitama, Japan.

Address for correspondence: Hiroaki Hamada, MD, Department of Medicine I, National Defense Medical College, 3-2, Namiki, Tokorozawa 359, Japan.

Received for publication December 26, 1996.

Accepted February 17, 1997. 
study, we created a rat ventricular hypertrophy model using subcutaneously implanted osmotic mini-pumps that delivered norepinephrine (NE), and examined the relationship between the sympathetic nervous system and aging in the development of ventricular hypertrophy.

\section{Methods}

Osmotic mini-pumps (Alzet model 2002) were implanted subcutaneously on the dorsum of 5- and 37- week-old male Sprague Dawley (SD) rats (Charles River Laboratories, Inc., Boston, MA, USA) under ether anesthesia. The mode of action of these pumps in vivo has been described by Patel et al. ${ }^{8}$ and King et al. ${ }^{9)}$ The pumps deliver solution at rate of $0.5 \mu l /$ hour into surrounding tissues. The concentrations of delivered drug can be adjusted by changing concentrations of solution in the pump. Blood pressures (BP) and heart rates (HR) were measured by the tail cuff method prior to euthanasia.

At appropriate times following the experimental protocol, the rats were decapitated while under deep ether anesthesia and the hearts removed. Body weight (BW) and ventricle weight (VW) were recorded and both right and left ventricle-to-body weight $(\mathrm{V} / \mathrm{B})$ ratios calculated.

Membrane preparation: The technique described by Liemas and Liemas ${ }^{10}$ was used. The excised heart was minced with scissors and homogenized with a polytron: PT 10 (Kinematica, Lucerne, Switzerland) (Set 5, $20 \mathrm{sec}$ ) in Buffer A (250 mM sucrose, $1 \mathrm{mM} \mathrm{NaHCO}, 1 \mathrm{mM} \mathrm{MgCl}_{2}, \mathrm{pH} \mathrm{7.4)} \mathrm{at} 4^{\circ} \mathrm{C}$. The homogenate was centrifuged at $500 \times \mathrm{g}$ for $10 \mathrm{~min}$ at $4^{\circ} \mathrm{C}$, the supernatant filtered through double gauze and then centrifuged again at $40,000 \times \mathrm{g}$ for $20 \mathrm{~min}$ at $4^{\circ} \mathrm{C}$. After centrifugation, the pellet was resuspended in Buffer A, homogenized by the potter technique, and centrifuged again at $40,000 \times \mathrm{g}$ for $20 \mathrm{~min}$ at $4^{\circ} \mathrm{C}$. The pellet was resuspended in Buffer $\mathrm{B}(50 \mathrm{mM}$ Tris, $10 \mathrm{mM} \mathrm{MgCl}, 2 \mathrm{mM}$ EGTA, pH 7.4), frozen, and stored at $-70^{\circ} \mathrm{C}$ until measurement.

Binding assay: Following the technique described by Vatner et al., (1) 8 graded concentrations (240 to $3,000 \mathrm{pM}$ ) of ${ }^{125}$ I-iodocyanopindolol (ICYP) (NEN, specific activity $2200 \mathrm{Ci} / \mathrm{mmol}$ ) and crude membranes were incubated at $37^{\circ} \mathrm{C}$ for $60 \mathrm{~min}$ and filtered through Whatman GF/C glass fiber filters (Whatman Inc., Clifton, NJ). The amount of ${ }^{125} \mathrm{I}-\mathrm{ICYP}$ on the filter was measured by a gamma counter. Non-specific binding was assessed under $6 \mu \mathrm{M}$ propranolol. The results were analyzed by Scatchard analysis and the density of $\beta$-adrenergic receptors (Bmax) and dissociation constant $(\mathrm{Kd})$ calculated. Sixteen graded concentrations $\left(6 \times 10^{-4} \mathrm{M}\right.$ to $\left.1.5 \times 10^{-8} \mathrm{M}\right)$ of $(-)$-ISO-HCl were prepared. With these solutions, $300 \mathrm{pM}{ }^{125} \mathrm{I}-\mathrm{ICYP}$ and crude membranes were incubated at $37^{\circ} \mathrm{C}$ for $30 \mathrm{~min}$. After filtration through a Whatman GF/C glass fiber filter, the amount of ${ }^{125} \mathrm{I}$ - 
ICYP on the filter was measured using a gamma counter. The study was repeated under $\mathrm{Gpp}(\mathrm{NH}) \mathrm{p}$ and the affinity for ISO in the presence and absence of $\mathrm{Gpp}(\mathrm{NH}) \mathrm{p}$ was calculated with a computer-assisted program, 'Ligand', developed by Munson and Rodbard, ${ }^{12)}$ which uses the F-test for the best fit.

Adenylyl cyclase activity was assayed according to the method of Homma et al. ${ }^{13)} 0.4 \mathrm{mM}$ IBMX, 0.5 mM App(NH)p, stimulants $(0.1 \mathrm{mM}$ ISO $+0.1 \mathrm{mM}$ GTP or $0.1 \mathrm{mM}$ Forskolin) and crude membrane were incubated at $37^{\circ} \mathrm{C}$ for 10 min, and cAMP was measured with a radioimmunoassay using a cAMP kit (Yamasa Shoyu K.K., Chiba, Japan). Changing Buffer A to Buffer 1 (250 mM sucrose, $1 \mathrm{mM} \mathrm{NaHCO}$, $1 \mathrm{mM}$ EGTA, pH 7.4) and Buffer B to Buffer 2 (100 mM Hepes, 2 mM EGTA, $\mathrm{pH}$ 7.6), crude membranes were prepared according to the same process, and the activity of adenylyl cyclase stimulated by $\mathrm{Mn}^{2+}$ was also measured.

The protein concentrations for each membrane assay were determined by the method of Lowry et al., ${ }^{14)}$ but assays of $\mathrm{Mn}^{2+}$ stimulation of adenylate cyclase were determined with Biorad protein assay kits (Biorad, Hercules, CA).

NE concentrations in ventricular myocardium wcrc measured by the HPLC method, and the 5'-nucleotidase activity was also determined as a measure of membrane volume, following the method of Hippel and Hilmoe. ${ }^{15}$ )

Student's t-test and Fisher's PLSD method were used to evaluate the significance of differences between groups. Differences were considered significant if $p \leq 0.05$.

Protocol, Study 1-1: To examine the changes in $\beta$-adrenergic receptors with aging, $\mathrm{NE}(1.0$ and $2.5 \mu \mathrm{g} / \mathrm{kg} / \mathrm{min}$ ) was administered to 5 and 37 -week-old male $\mathrm{SD}$ rats for 14 days; $n=8$ in each group. The rats were sacrificed at the end of the 14-day treatment period and BW, HR, BP, VW, $\beta$-adrenergic receptor density and adenylyl cyclase activity were measured; ventricles were examined histologically. The NE used was in the form of an HCl salt (Sigma A7381, MW 205.6).

Protocol, Study 1-2: The ventricular hypertrophy model in the present study was generated by an osmotic mini-pump. To this model, we added a second dorsal subcutaneous pump that administered an $\alpha$-1 blocker (bunazosin, kindly provided by Eisai Co., Ltd, Tokyo, Japan) or a $\beta$-1 blocker (bisoprolol, kindly provided by Tanabe Seiyaku Co., Osaka, Japan) with NE simultaneously to examine suppressive effects on ventricular hypertrophy. Because 5-week-old Sprague Dawley rats weigh 150-160 g and the implantation of two pumps would be too invasive, we used 6-week-old male SD rats in this part of the study. The drugs and dosages administered by the 2 pumps in the rats of each group were as follows:

Group 1, $n=4$ : pump 1, NE $(2.5 \mu \mathrm{g} / \mathrm{kg} / \mathrm{min}) ;$ pump 2, $0.9 \%$ saline; 
Group 2, $n=4$ : pump 1, NE $(2.5 \mu \mathrm{g} / \mathrm{kg} / \mathrm{min})$; pump 2, bunazosin $\left(1.71 \times 10^{-7} \mathrm{~mol} / \mathrm{kg} / \mathrm{min}\right)$

Group 3, $n=5$ : pump 1, NE $(2.5 \mu \mathrm{g} / \mathrm{kg} / \mathrm{min})$; pump 2, bunazosin $\left(8.53 \times 10^{-8} \mathrm{~mol} / \mathrm{kg} / \mathrm{min}\right)$;

Group 4, $n=4$ : pump 1, NE (2.5 $\mu \mathrm{g} / \mathrm{kg} / \mathrm{min})$; pump 2, bisoprolol $\left(4.40 \times 10^{-7} \mathrm{~mol} / \mathrm{kg} / \mathrm{min}\right)$;

Group 5, $n=3$ : pump 1, NE (2.5 $\mu \mathrm{g} / \mathrm{kg} / \mathrm{min})$; pump 2, bisoprolol $\left(2.20 \times 10^{-7} \mathrm{~mol} / \mathrm{kg} /\right.$ day $)$.

Protocol, Study 2: The manufacturer stopped production of the $\mathrm{HCl}$ salt of NE, forcing us to change to a bitartate salt of NE (Sigma A7825, MW 319.3). We made preliminary studies again to determine a suitable concentration and delivery time of bitartate salts of NE for 5-week-old SD rats. Ascorbic acid $(0.1 \mathrm{mg} /$ $\mathrm{m}$ ) was added to serve as an antioxidative agent. Throughout the preliminary studies, the bitartate salt of NE $(3.0 \mu \mathrm{g} / \mathrm{kg} / \mathrm{min})$ for 7 days was thought to be sufficiènt to induce ventricular hypertrophy.

NE $(3.0 \mu \mathrm{g} / \mathrm{kg} / \mathrm{min})$ or $0.9 \%$ saline was administered to 5-week-old male $\mathrm{SD}$ rats for 7 continuous days continuously, and pre- and post BW, HR, BP and post VW were measured. Crude membrane preparations were made to measure $\beta$-adrenergic receptor density, affinity and adenylyl cyclase activity. $5^{\prime}$-nucleotidase activity was measured to use as an inner standard for crude membrane measurements. NE concentration in ventricles was measured by HPLC.

\section{Results}

Study 1-1: The density of $\beta$-adrenergic receptors, dissociation constant, and activity of adenylyl cyclase were significantly reduced $(p<0.05)$ in 37 week old rats compared to 5 week old rats (Table $\mathrm{I})$. $\mathrm{NE}(1.0 \mu \mathrm{g} / \mathrm{kg} / \mathrm{min})$ administration to 5 week old rats for 14 days decreased V/B (Table II-1) but a higher dose level of

Table I. Changes of Beta-adrenergic Receptor and Adenylyl Cyclase Activity with Advancing Age in SD rats.

\begin{tabular}{lcc}
\hline & \multicolumn{2}{c}{ Age of rats } \\
\cline { 2 - 3 } & 5 weeks & 37 weeks \\
\hline & $(n=8)$ & $(n=8)$ \\
$\beta$-AR: Bmax $(\mathrm{fmol} / \mathrm{mg})$ & $108.2 \pm 10.8$ & $47.4 \pm 7.1^{*}$ \\
$\mathrm{Kd}(\mathrm{nM})$ & $0.146 \pm 0.036$ & $0.073 \pm 0.020^{*}$ \\
AC-assay: basal $(\mathrm{pmol} / \mathrm{mg} / \mathrm{min})$ & $6.4 \pm 1.2$ & $5.8 \pm 0.9$ \\
AC-assay: $\mathrm{ISO}+\mathrm{GTP}(\mathrm{pmol} / \mathrm{mg} / \mathrm{min})$ & $24.2 \pm 5.8$ & $9.5 \pm 1.2^{*}$ \\
\hline
\end{tabular}

Values are mean $\pm \mathrm{SD} ; * p<0.05 ; \beta$-AR: $\mathrm{Bmax}, \beta$-adrenergic receptor density; $\mathrm{Kd}=$ dissociation constant; $A C$-assay: basal $=$ non-stimulated cAMP quantity; $A C$ - assay $=I S O+G T P$, isoproterenol + GTP-stimulated cAMP quantity. 
Table II. The Administration of NE-HCl $(1.0 \mu \mathrm{g} / \mathrm{kg} / \mathrm{min}$ and $2.5 \mu \mathrm{g} / \mathrm{kg} / \mathrm{min})$ for 14 Days in 5-week-old SD rats

\begin{tabular}{lcc}
\hline 1. $\mathrm{NE}(1.0 \mu \mathrm{g} / \mathrm{kg} / \mathrm{min})$ & Control & $\mathrm{NE}$ \\
& $(n=8)$ & $(n=8)$ \\
$\mathrm{BW}(\mathrm{g})$ & $280.8 \pm 8.1$ & $275.3 \pm 13.6$ \\
$\mathrm{HR}(\mathrm{bpm})$ & $391.0 \pm 14.5$ & $397.0 \pm 25.0$ \\
$\mathrm{BP}(\mathrm{mmHg})$ & $118.4 \pm 13.0$ & $116.5 \pm 11.1$ \\
$\mathrm{VW}(\mathrm{mg})$ & $897.3 \pm 47.2$ & $933.7 \pm 54.3$ \\
$\mathrm{~V} / \mathrm{B}(\mathrm{mg} / \mathrm{g})$ & $3.20 \pm 0.18$ & $3.40 \pm 0.21^{*}$ \\
\hline $\mathrm{NE}(2.5 \mu \mathrm{g} / \mathrm{kg} / \mathrm{min})$ & & $\mathrm{NE}$ \\
& Control & $(n=8)$ \\
& $(n=8)$ & $265.4 \pm 14.8^{*}$ \\
$\mathrm{BW}(\mathrm{g})$ & $289.1 \pm 8.1$ & $407.5 \pm 14.9$ \\
$\mathrm{HR}(\mathrm{bpm})$ & $398.8 \pm 8.3$ & $118.0 \pm 4.8$ \\
$\mathrm{BP}(\mathrm{mmHg})$ & $117.5 \pm 4.6$ & $1312.9 \pm 126.2^{*}$ \\
$\mathrm{VW}(\mathrm{mg})$ & $1026.4 \pm 76.8$ & $4.95 \pm 0.48^{*}$ \\
$\mathrm{~V} / \mathrm{B}(\mathrm{mg} / \mathrm{g})$ & $3.55 \pm 0.29$ & \\
\hline
\end{tabular}

Values are mean $\pm \mathrm{SD} ; \mathrm{BW}=$ body weight; $\mathrm{HR}=$ heart rate; $\mathrm{BP}=$ blood pressure; $\mathrm{VW}=$ ventricular weight; $\mathrm{V} / \mathrm{B}=$ ventricular to body weight ratio; $* p<0.05$
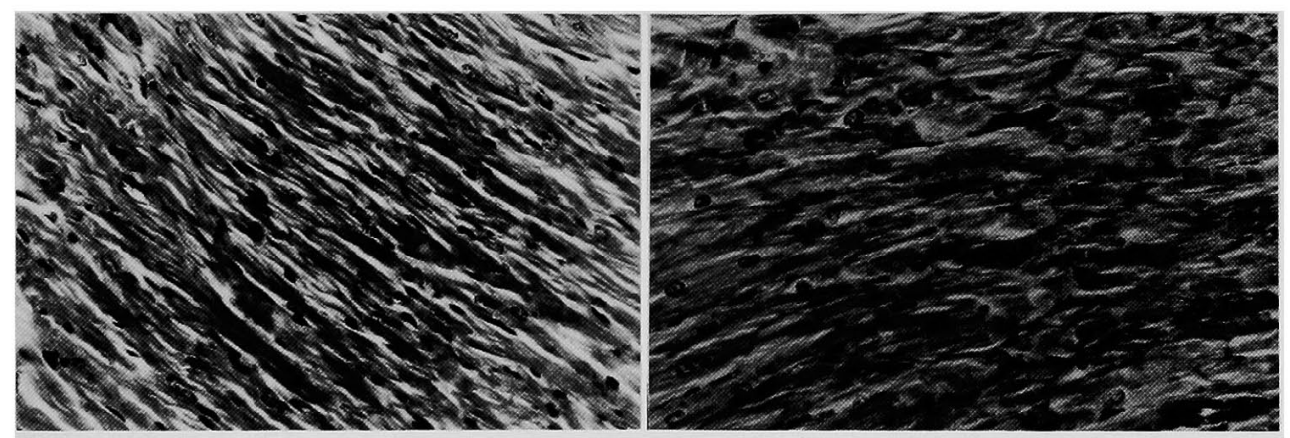

Figure 1. The left ventricles of 5 week old SD rats. (Left) control rat, infused with $0.9 \%$ saline for 14 days. (Right) experimental rat, infused with $\mathrm{NE}(2.5 \mu \mathrm{g} / \mathrm{kg} / \mathrm{min})$ for 14 days.

$\mathrm{NE}(2.5 \mu \mathrm{g} / \mathrm{kg} / \mathrm{min})$ for 14 days led to significant $(p<0.05)$ ventricular hypertrophy and increased V/B without changes in HR and BP (Table II-2) and there was no necrosis of myocardium and interstitial fibrosis (Figure 1); BW was significantly $(p<0.05)$ reduced. In 37 week old rats, NE at the higher dose level $(2.5$ $\mu \mathrm{g} / \mathrm{kg} / \mathrm{min})$ was lethal, and even at the lower dose level $(1.0 \mu \mathrm{g} / \mathrm{kg} / \mathrm{min}) \mathrm{NE}$ caused increased HR $(p<0.05)$ and decreased BW $(p<0.05)$ (a tendency to heart failure) but no significant ventricular hypertrophy (Table III). Histological examination revealed myocardial necrosis with an invasion of small round mononuclear cells and interstitial fibrosis, which were not found in the ventricles of control rats (Figure 2). 
Table III. The Administration of NE-HCl $(1.0 \mu \mathrm{g} / \mathrm{kg} / \mathrm{min})$ for 14 Days in 37 -week-old SD Rats

\begin{tabular}{lcc}
\hline & Control & NE $(\mathrm{I} .0)$ \\
& $(n=8)$ & $(n=7)$ \\
BW $(\mathrm{g})$ & $623.5 \pm 43.8$ & $582.2 \pm 24.5^{*}$ \\
HR $(\mathrm{bpm})$ & $325.0 \pm 10.7$ & $357.1 \pm 39.9^{*}$ \\
BP $(\mathrm{mmHg})$ & $110.1 \pm 6.1$ & $115.1 \pm 6.1$ \\
VW $(\mathrm{mg})$ & $1635.0 \pm 160.4$ & $1681.0 \pm 140.6$ \\
V/B $(\mathrm{mg} / \mathrm{g})$ & $2.64 \pm 0.35$ & $2.90 \pm 0.34$ \\
\hline
\end{tabular}

Values are mean $\pm \mathrm{SD} ; \mathrm{BW}=$ body weight; $\mathrm{HR}=$ heart rate; $\mathrm{BP}=$ blood pressure; $\mathrm{VW}=$ ventricular weight; $\mathrm{V} / \mathrm{B}=$ ventricular to body weight ratio; $* p<0.05$

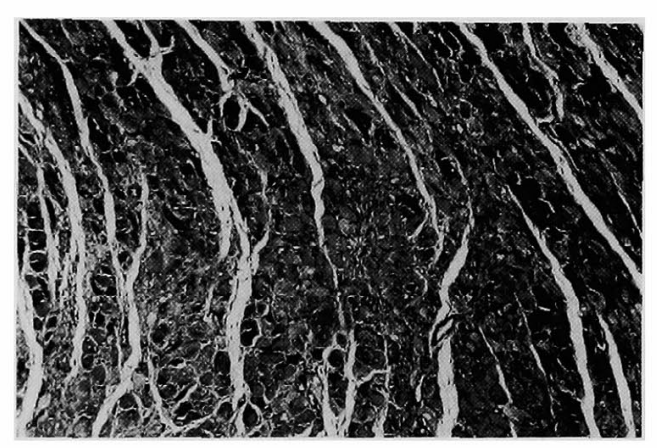

Figure 2. The left ventricles of 37 week old SD rats infused with $\mathrm{NE}(1.0 \mu \mathrm{g} / \mathrm{kg} /$ $\min$ ) for 14 days.

Table IV. The Simultaneous Administration of NE-HCl $(2.5 \mu \mathrm{g} / \mathrm{kg} / \mathrm{min})+\alpha-1$ (Bunazosin) or $\beta$-1 Blocker (Bisoprolol) for 14 Days in 6-week-old SD Rats

\begin{tabular}{|c|c|c|c|c|c|}
\hline & $\begin{array}{c}\text { Group } 1 \\
(n=4)\end{array}$ & $\begin{array}{c}\text { Group } 2 \\
(n=5)\end{array}$ & $\begin{array}{c}\text { Group } 3 \\
(n=5)\end{array}$ & $\begin{array}{c}\text { Group } 4 \\
(n=4)\end{array}$ & $\begin{array}{c}\text { Group } 5 \\
(n=3)\end{array}$ \\
\hline \multicolumn{6}{|c|}{ At the start of the study: } \\
\hline $\mathrm{BW}(\mathrm{g})$ & $179.7 \pm 4.0$ & $176.1 \pm 7.9$ & $177.7 \pm 3.5$ & $176.9 \pm 4.6$ & $181.9 \pm 2.5$ \\
\hline HR (bpm) & $415.0 \pm 17.3$ & $398.0 \pm 20.5$ & $420.0 \pm 18.7$ & $427.5 \pm 15.0$ & $430.0 \pm 20.0$ \\
\hline $\mathrm{BP}(\mathrm{mmHg})$ & $113.0 \pm 10.9$ & $103.0 \pm 5.2$ & $111.2 \pm 11.5$ & $124.3 \pm 5.4$ & $113.7 \pm 4.0$ \\
\hline \multicolumn{6}{|c|}{ After 14 days of drug administration: } \\
\hline $\mathrm{BW}(\mathrm{g})$ & $214.6 \pm 15.8$ & $282.3 \pm 13.6 *$ & $260.2 \pm 33.8^{*}$ & $240.3 \pm 14.7^{*}$ & $251.1 \pm 8.3^{*}$ \\
\hline $\mathrm{HR}$ (bpm) & $385.0 \pm 61.9$ & $370.0 \pm 23.5$ & $372.5 \pm 35.0$ & $365.0 \pm 33.2$ & $353.3 \pm 25.2$ \\
\hline $\mathrm{BP}(\mathrm{mmHg})$ & $121.5 \pm 19.1$ & $105.4 \pm 46.6$ & $122.8 \pm 13.8$ & $131.8 \pm 4.5$ & $135.7 \pm 1.2$ \\
\hline VW (mg) & $1215 \pm 117$ & $1185 \pm 66$ & $1124 \pm 58$ & $1146 \pm 112$ & $1165 \pm 92$ \\
\hline $\mathrm{V} / \mathrm{B}(\mathrm{mg} / \mathrm{g})$ & $5.67 \pm 0.71$ & $4.20 \pm 0.29 *$ & $4.38 \pm 0.60^{*}$ & $4.76 \pm 0.18^{*}$ & $4.63 \pm 0.21^{*}$ \\
\hline \multicolumn{6}{|c|}{ Group 1 , controls: $\mathrm{NE}+0.9 \%$ saline } \\
\hline \multicolumn{6}{|c|}{ Group 2: NE + Bunazosin $\left(1.71 \times 10^{-7} \mathrm{~mol} / \mathrm{kg} /\right.$ day $)$} \\
\hline \multicolumn{6}{|c|}{ Group 3: NE + Bunazosin $\left(8.53 \times 10^{-8} \mathrm{~mol} / \mathrm{kg} /\right.$ day $)$} \\
\hline \multicolumn{6}{|c|}{ Group 4: NE + Bisoprolol $\left(4.40 \times 10^{-7} \mathrm{~mol} / \mathrm{kg} /\right.$ day $)$} \\
\hline \multicolumn{6}{|c|}{ Group 5: NE + Bisoprolol $\left(2.20 \times 10^{-7} \mathrm{~mol} / \mathrm{kg} /\right.$ day $)$} \\
\hline
\end{tabular}

Values are mean $\pm \mathrm{SD},{ }^{*} p<0.05$ between treatment and controls (Treatment 1). BW= body weight; $\mathrm{HR}=$ heart rate $\mathrm{BP}=$ blood pressure; $\mathrm{VW}=$ ventricular weight $\mathrm{V} / \mathrm{B}=$ ventricular to body weight ratio. 
Table V. The Administration of NE-Bitartate $(3.0 \mu \mathrm{g} / \mathrm{kg} / \mathrm{min})$ for 7 Days in 5 -week-old SD Rats

\begin{tabular}{|c|c|c|}
\hline & $\begin{array}{l}\text { Gontrol } \\
(n=8)\end{array}$ & $\begin{array}{c}\text { NE }(3.0) \\
(n=8)\end{array}$ \\
\hline 7 days-BW $(g)$ & $195.5 \pm 7.3$ & $190.1 \pm 8.6$ \\
\hline $\mathrm{BP}(\mathrm{mmHg})$ & $113.4 \pm 11.3$ & $129.5 \pm 14.9^{*}$ \\
\hline HR (bpm) & $413.0 \pm 16.2$ & $388.5 \pm 22.7^{*}$ \\
\hline $\mathrm{VW}(\mathrm{mg})$ & $729.6 \pm 53.7$ & $870.9 \pm 88.5^{*}$ \\
\hline $\mathrm{V} / \mathrm{B}(\mathrm{mg} / \mathrm{g})$ & $3.74 \pm 0.28$ & $4.66 \pm 0.31^{*}$ \\
\hline \multicolumn{3}{|l|}{$\beta$-AR: } \\
\hline :Bmax $(\mathrm{fmol} / \mathrm{mg})$ & $118.8 \pm 16.4$ & $80.5 \pm 20.9^{*}$ \\
\hline$: \mathrm{Kd}(\mathrm{nmM})$ & $0.119 \pm 0.051$ & $0.130 \pm 0.062$ \\
\hline \multicolumn{3}{|l|}{ AC-assay } \\
\hline basal $(\mathrm{pmol} / \mathrm{mg} / \mathrm{min})$ & $6.4 \pm 1.2$ & $5.3 \pm 1.0$ \\
\hline$: \mathrm{ISO}+\mathrm{GTP}(\mathrm{pmol} / \mathrm{mg} / \mathrm{min})$ & $24.2 \pm 5.8$ & $19.7 \pm 8.7$ \\
\hline :Forskolin $(\mathrm{pmol} / \mathrm{mg} / \mathrm{min})$ & $144.3 \pm 22.8$ & $131.3 \pm 40.0$ \\
\hline $\mathrm{Mn}^{2+}(\mathrm{pmol} / \mathrm{mg} / \mathrm{min})$ & $155.6 \pm 10.8$ & $130.9 \pm 18.8$ \\
\hline
\end{tabular}

Values are mean $\pm \mathrm{SD} ; *<<0.05 ; \quad \mathrm{HR}=$ heart rate; $\mathrm{BP}=$ blood pressure; $\mathrm{VW}=$ ventricular weight; $\mathrm{V} /$ $\mathrm{B}=$ ventricular to body weight ratio; $\beta$-AR: $\mathrm{Bmax}, \mathrm{b}$-adrenergic receptor density; $\beta-\mathrm{AR}: \mathrm{Kd}=$ dissociation constant; AC-assay: basal = non-stimulated cAMP quantity; AC-assay: $I S O+G T P=$ isoproterenol + GTPstimulated cAMP quantity; $\mathrm{AC}$-assay: forskolin = forskolin-stimulated cAMP quantity; $\mathrm{AC}$-assay: $\mathrm{Mn}^{2+}=\mathrm{Mn}^{2+}-$ stimulated CAMP quantity.

Table VI. The Changes of NE Content and 5'.Nucleotidase Activity in the NE-Bitartate $(3.0 \mu \mathrm{g} / \mathrm{kg} / \mathrm{min})$ Stimulated 7 Days Hypertrophied Ventricles in 5-week-old SD Rats

\begin{tabular}{ccc}
\hline & $\begin{array}{c}\text { NE content } \\
(\mathrm{ng} / \mathrm{g})\end{array}$ & $\begin{array}{l}5^{\prime} \text {-nucleotidase activity } \\
(\mu \mathrm{mmol} / \mathrm{mg} / \mathrm{min})\end{array}$ \\
\hline Control & $771.6 \pm 429.2(n=9)$ & $1.65 \pm 0.74(n=8)$ \\
NE $(3.0)$ & $467.9 \pm 119.1 *(n=7)$ & $1.70 \pm 0.57(n=7)$ \\
\hline
\end{tabular}

Values are mean $\pm \mathrm{SD} ; * p<0.05$.

Study 1-2: HR, BP and VW were not significantly affected by 14 days of treatment with NE $(2.5 \mu \mathrm{g} / \mathrm{kg} / \mathrm{min}$ ) plus either an $\alpha$-1 blocker (bunazosin) or a $\beta$-1 blocker (bisoprolol), but $\mathrm{BW}$ and therefore $\mathrm{V} / \mathrm{B}$ ratios were significantly $(p<0.05)$ reduced compared to rats receiving NE plus $0.9 \%$ saline (Table IV).

Study 2: The administration of NE $(3.0 \mu \mathrm{g} / \mathrm{kg} / \mathrm{min})$ for 7 days induced significant ventricular hypertrophy with decreased HR and increased BP (Table V). Histologically, there was no myocardial necrosis or interstitial fibrosis in the hypertrophied ventricles. The density and affinity of $\beta$ adrenergic receptors was significantly $(p<0.05)$ decreased in the hypertrophied ventricles. There were no significant differences in the activity of adenylyl cyclase. NE content was significantly $(p<0.05)$ lower in the hypertrophied ventricles, but the differences between groups with respect to 5 '-nucleotidase activities were not significant (Table VI). 


\section{Discussion}

When we discuss changes in the sympathetic nervous system with ventricular hypertrophy, we must also consider the dilution of receptors on membranes with hypertrophy. We measured the 5'-nucleotidase activity of crude membranes as membrane units. Because there were no significant differences between controls and hypertrophied ventricles, we ignored the effect of dilution in these studies. Fibroblasts contain more $\beta-2$ adrenergic receptors than do cardiomyocytes. ${ }^{16)}$ If the ventricles have necrotic areas, $\beta-1$ adrenergic receptors are underestimated. We examined the ventricles histologically and found no necrotic areas or interstitial fibrosis in hypertrophied ventricles.

The doses of bunazosin and bisoprolol used in the present experiment were determined from standard doses for humans in proportion to BW (Groups 2 and 4) and double that dose (Groups 3 and 5). Bunazosin and bisoprolol suppressed the body weight loss. The reason for this suppression seems to be through the extra-cardiac $\alpha$ - and $\beta$-adrenergic receptors. VW did not change significantly so an anti-hypertrophic effect of these drugs was not detected in the present experiments.

By the continuous i.v. infusion of NE for 3 days, the rapid development of cardiac hypertrophy seemed to be directly stimulated by myocardial $\alpha$ - and $\beta$ adrenoceptors rather than by hemodynamic changes. ${ }^{6)}$ In a conscious dog model, the administration of $\mathrm{NE}(0.5 \mu \mathrm{g} / \mathrm{kg} / \mathrm{min}$ for 28 days $)$ caused a decreased $\mathrm{HR}$, cardiac output and no BP change. ${ }^{8)}$ In our rat model, the $\mathrm{NE} \mathrm{HCl}$ salt $(2.5 \mu \mathrm{g}$ / $\mathrm{kg} / \mathrm{min}, 12.2 \mathrm{nM} / \mathrm{kg} / \mathrm{min}$ ) administered for 14 days caused ventricular hypertrophy without $\mathrm{HR}$ and $\mathrm{BP}$ changes, and the NE tartate salt $(3.0 \mu \mathrm{g} / \mathrm{kg} / \mathrm{min}, 9.4$ $\mathrm{nM} / \mathrm{kg} / \mathrm{min}$ ) for 7 days caused ventricular hypertrophy with decreased $\mathrm{HR}$ and increased BP. The difference between the two NE salts is thought to be due to their stability at room temperature; NE tartate salt is more stable at room temperature. BP and $\mathrm{HR}$ are thought to be concentration-dependent on NE, and incrcased BP is not considered to be indispensable for ventricular hypertrophy in this modcl.

NE has $\alpha>\beta$-adrenergic stimulation and in the NE stimulated hypertrophicd ventricle there was downregulation to at least the $\beta$-adrenergic receptor levels. NE concentrations in myocardium did not reflect the activity of the sympathetic nervous system in an aortic banding model. ${ }^{17)}$ In a pacing-induced dog heart failure model, the NE uptake of the myocardium decreased and interstitial $\mathrm{NE}$ conccntration increased with increasing serum $\mathrm{NE}$ concentrations in the heart failure group. ${ }^{18)}$ Although NE concentrations in myocardium deffer in the experimental modcls, in our model the decrease of NE content of myocardium seemed to reflect the disorder of ventricular sympathetic nervous system with 
down regulation of the $\beta$ adrenergic receptor systems. Kondo et al. ${ }^{199}$ report that noradrenergic hyper-innervation in the subepicardium and myocardium of the ventricles of stroke-prone spontaneously hypertensive rats (SHRSP) may be a primary change of the heart before the onset of hypertension. This hyper-innervation of noradrenergic nerves is possibly thought to be a transient phenomenon between compensative and non-compensative cardiac hypertrophy.

$\beta$-adrenergic-mediated myocardial inotropic and chronotropic responsiveness reportedly decreases with aging. ${ }^{20\rangle}$ Others reported that the overall cardiovascular response to $\mathrm{NE}$ was unaffected by aging in $\mathrm{SD}$ rats. ${ }^{21)}$ In Fischer 344 rats, the decrease in myocardial beta-adrenergic responsiveness with aging was believed to be unrelated to delayed or incomplete recovery of $\beta$-adrenoceptor density after agonist-induced down-regulation. ${ }^{22}$ Tobise et al. ${ }^{23)}$ reported that age-related changes in the activity of the myocardial $\beta$-adrenergic receptor-Gsadenylyl cyclase pathway was not primary regulated by alteration in the level of Gs or Gi but by the density of $\beta$-adrenergic receptors and by the activity of the catalyst adenylyl cyclase, and in particular the decrease in the steady-state mRNA content of the type VI isoform of adenylyl cyclase correlated with catalytic activity with age.

In our model, $\beta$-adrenergic receptor systems were attenuated with aging. The loading of NE caused cardiac hypertrophy in younger rats, but caused cardiac injury at lower doses in aged rats. Cardiac injury caused by NE was through activation of the $\alpha$-adrenergic receptor system in a rabbit model. ${ }^{24)}$ However, rat ventricular $\alpha$-adrenoceptors, measured by specific binding of $\left[{ }^{3} \mathrm{H}\right]$ prazosin, was reported to decrease by $33 \%$ in rats aged from 3 to 24 months. ${ }^{25)}$ According to the above results, the cardiotoxicity of NE to the aged rat was thought to be dependent on the changes of $\alpha$ and $\beta$ adrenoceptors with aging. In cultured adult cardiomyocytes, NE caused an increase of intracellular cAMP and $\mathrm{Ca}^{2+}$ and decreased viability. ${ }^{26)}$ The association between catecholamines and cardiotoxicity has previously been studied. ${ }^{27-31)}$ The mechanisms are believed to be attributed to impaircd intracellular $\mathrm{Ca}^{2+}$ handling, reduced coronary blood flow, and formation of highly cytotoxic free radicals derived from catecholamine auto-oxidation. In the aged rat, the cardiotoxicity of NE might be due to decreased activity of superoxide dismutasc ${ }^{32)}$ that scavenges cytotoxic free radicals. It seems worthwhile to investigate the cardioprotective effect of superoxide dismutase in these aged rats. The results of these studies indicate that NE caused myocardial injury more severely in older rats with decreasing $\beta$ adrenergic function. The function of $\beta$ adrenergic receptors is thought to play important roles in the protection of the myocardium against excessive NE. 


\section{References}

1. Simpson P, McGrath A, Savion S. Myocyte hypertrophy in neonatal rat heart cultures and its regulation by catecholamines. Circ Res 1982; 51: 787-801.

2. Simpson P. Stimulation of hypertrophy of cultured neonatal rat heart cells through an alpha-1 adrenergic receptor and interaction: evidence for independent regulation of growth and beating. Circ Res 1985; 56: 884-94.

3. Fisher JE, Horst WD, Kopin IJ. Norepinephrine metabolism in hypertrophied rat hearts. Nature 1965; 207: 952-3.

4. Tarazi RG, Sen S. The multifactorial role of catecholamines in hypertensive cardiac hypertrophy. Eur Heart J 1982; 3 (Suppl A): 103-10.

5. Yamori Y, Tarazi RC. Effect of beta-receptor-blocking agents on cardiovascular structural changes in spontaneous and noradrenaline-induced hypertension in rats. Clin Sci 1980; 59 (Suppl 6): 457-60.

6. Zierhut W, Zimmer, H-G. Significance of myocardial alpha and beta-adrenoceptors in catecholamine-induced cardiac hypertrophy. Circ Res 1989; 65: 1417-25.

7. Cooper G, Kent, RL, Uboh CE, Thompson EW, Marino TA. Hemodynamic versus adrenergic control of cat right ventricular hypertrophy. J Clin Invest 1985; 75: 1403-14.

8. Patel MB, Loud AV, King BD, Anversa D, Sack D, Hintze TH. Global myocardial hypertrophy in conscious dogs with chronic elevation of plasma norepinephrine in conscious dogs. J Mol Cell Cardiol 1989; 21 (Suppl V): 49-61.

9. King BD, Sack D, Kichuk MR, Hintze TH. Absence of hypertension despite chronic marked elevations in plasma norepinephrine in conscious dogs. Hypertension 1987; 9: 582-90.

10. Liemas CJ, Liemas C. Altered intracellular adrenoceptor distribution in myocardium of spontaneously hypertensive rats. Heart Circ Physiol 1987; 22: H904-H908.

11. Vatner DE, Vatner SF, Fujii AM, Homocy CJ. Loss of high affinity cardiac beta adrenergic receptors in dogs with heart failure. J Clin Invest 1985; 76: 2259-64.

12. Munson PJ, Rodbard D. Ligand: a versatile computerized approach for characterization of ligandbinding systems. Anal Biochem 1980; 107: 220-39.

13. Honma $M$, Sato $T$, Takezawa J, Ui $M$. An ultrasensitive method for the simultaneous determination of cyclic AMP and cyclic GMP in small-volume samples from blood and tissue. Biochem Med 1977; 18: 257-73.

14. Lowry $\mathrm{OH}$, Rosenbrough NJ, Farr AL, Randall RJ. Protein measurement with folin phenol reagent. J Biol Chem I95I; 193: 265-75.

15. Hippel LA, Hilmoe RJ. $5^{\prime}$ Nucleotidases. In: Colowich SP and Kaplan NO, editors. Methods in Enzymology 2. New York: Academic Press, 1955: 546-550.

16. Lau YH, Robinson RB, Rosen MR, Bilenzikian JP. Circ Res 1980; 47: 41-8.

17. Ganguly PK, Lee SL, Beamish RE, Dhalla NS. Altered sympathetic system and adrenoceptors during the development of cardiac hypertrophy. Am Heart J 1989; 118: 520-5.

18. Delenhanty JM, Himuro $\mathrm{Y}$, Elam H, Hood WB Jr, Liang C-S. Beta-adrenoceptor downregulation in pacing-induced heart failure is associated with increased interstitial NE content. Am J Physiol 1994; 266: H930-H935.

19. Kondo M, Fujiwara T, Tabei R. Noradrenergic hyperinnervation in the heart of stroke-prone spontaneously hypertensive rats (SHRSP). Hypertens Res 1996; 19: 69-73.

20. Fleg JL. Alterations in cardiovascular structure and function with advancing age. Am J Cardiol 1986; 57: $33 \mathrm{C}-44 \mathrm{C}$.

21. Docherty JR, Hyland L. Alpha-adrenergic responsiveness in the aged rat. Eur J Pharmacol 1986; 126: 75-80.

22. Raitt MR, Tamblyn C, Allen JM, Abrass IB. Beta-adrenergic receptor downregulation and recovery in heart and lung in the Fischer 344 rat: effect of aging and correlation with mRNA levels. J Gerontol 1995; 50A: B213-B217.

23. Tobise $\mathrm{K}$, Ishikawa $\mathbf{Y}$, Holmer SR, et al. Changes in type VI adenylyl cyclase isoform expression correlate with a decreased capacity for cAMP generation in the aging ventricle. Circ Res 1994; 74: 596603. 
24. Downing SE, Lee JC. Contribution of alpha-adrenoceptor activation to the pathogenesis of norepinephrine cardiomyopathy. Circ Res 1983; 52: 471-78.

25. Partilla JS, Hoopes MT, Ito H, Dax EM, Roth GS. Loss of rat ventricular alpha-adrenergic receptors during aging. Life Sci 1982; 31: 2507-12.

26. Mann DL, Kent RL, Parsons B, Cooper IV G. Adrenergic effects on the biology of the adult mammalian cardiocyte. Circulation 1992; 85: 790-804.

27. Caspi J, Coles JG, Benson LN, Herman SL, Diaz R, Augustine J, Brezina A, Kolin A, Wilson GJ. Agerelated response to epinephrine induced myocardial stress. A functional and ultrastructural study. Circulation 1991; 84 (Suppl III) 394-9.

28. Varley KG, Dhalla NS. Excitation-contraction coupling in heart: XII. Intracellular calcium transport in isoproterenol-induced myocardial necrosis. Exp Mol Pathol 1973; 19: 94-105.

29. Caspi J, Censon LN, Herman SL, Act JA, Wilson GJ. Heart rate independence of catecholamineinduced myocardial damage in the newborn pig. J Pediatr Res 1994; 36: 49-54.

30. Singal PK, Kapur N, Dhillon KS, Beamish RE, Dhalla NS. Role of free radicals in catecholamineinduced cardiomyopathy. Can J Pharmacol 1982; 60: 1390-7.

31. Rump AFE, Klaus W. Evidence for norepinephrine cardiotoxicity mediated by superoxide anion radicals in isolated rabbit hearts. Naunyn Schmiedebergs Arch Pharmacol 1993; 349: 295-300.

32. McCord JM, Fridovich I. Superoxide dismutase. An enzymatic function for erythrocuprein (Hemocuprein). J Biol Chem 1969; 244: 6049-55. 